\begin{tabular}{|c|c|c|}
\hline 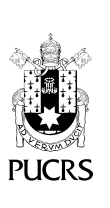 & $\begin{array}{l}\text { ESCOLA DE } \\
\text { HUMANIDADES }\end{array}$ & $\begin{array}{l}\text { Revista de Cultura e Literaturas de Língua Portuguesa } \\
\text { Navegações, Porto Alegre, v. 13, n. 2, p. 1-12, jul.-dez. } 2020 \\
\text { e-ISSN: 1983-4276 ISSN-L: 1982-8527 }\end{array}$ \\
\hline & $\mathrm{rg} / 10.15448 / 1983-4276.2020 .2$ & \\
\hline
\end{tabular}

SEÇÃO: ENSAIOS

\title{
Perfis femininos em Semear em pó, de Fátima Bettencourt
}

\author{
Female profiles in Semear o pó by Fátima Bettencourt
}

\section{Demétrio Alves Paz $^{1}$ \\ orcid.org/0000-0002-5305-290X demetrio.paz@uffs.edu.br}

\section{Letícia Gabriele Drey ${ }^{1}$ orcid.org/0000-0003-1332-1551 leti_drey@hotmail.com}

Recebido em: 5/9/2019. Aprovado em: 27/4/2020. Publicado em: 25/2/2021.

\section{(c) (1)}

Artigo está licenciado sob forma de uma licença Creative Commons Atribuicão 4.0 Internacional.
Resumo: No artigo analisamos três perfis femininos, presentes em seis contos da obra Semear em Pó (1994), da escritora cabo-verdiana Fátima Bettencourt, a partir da leitura de obras criticas de especialistas nas literaturas africanas de lingua portuguesa como Simone Caputo Gomes (2008) e da teoria da narrativa de Gérard Genette (2017). Levamos em conta as características marcantes na escrita dessa obra: a mulher como protagonista das histórias; o seu papel perante a família; a forma como introduz o modo de viver da sociedade de Cabo Verde; os problemas que, de algum modo, fizeram parte da história do país, assim como a voz e a pessoa da narração. Todos esses elementos aparecem como diferentes tipos de recordações pelas narradoras dos contos.

Palavras-chave: Literatura de autoria feminina. Conto. Literatura cabo-verdiana. Mulher. Identidade.

Abstract: In this article we analyze three female profiles present in the book Semear o pó (1994), by the Cape Verdean Writer Fátima Bettencourt, from the reading of critical works by scholars of African Literature in Portuguese Language such as Simone Caputo Gomes (2008) and the theory of narrative by Gerard Genette (2017). We take in account the main characteristics in the writing of this book: the woman as protagonist in the stories; her role before the family; the way in which is introduced the Cape Verdean society way of life; the problems that, somehow, are part of the History of the country, as well as the voice and the person in the narration. All these elements appear as different types of memories by the narrators of the short stories.

Keywords: Female authorship literature. Short story. Cape-Verdean literature. Woman. Identity.

\section{Introdução}

A condição feminina acompanhou a história e a política de Cabo Verde. Primeiramente, cabia à mulher somente o trabalho doméstico, já que as decisões sobre o lar e a educação dos filhos eram tomadas pelo homem. Com a emigração em massa e a ausência da figura masculina, a mulher passou a ser chefe da casa e da familia. Ao reconhecer o seu papel nessas tarefas, ela conseguiu efetivar-se no espaço público.

É notório que os movimentos feministas proporcionaram às mulheres serem vistas considerando suas particularidades e experiências. 0 feminismo trouxe uma mudança para o rosto da mulher ao reelaborar temas, contrapondo às representações típicas da escrita masculina, sobretudo, androcêntrica. A partir dessa nova concepção, as mulheres emergiram para outro espaço, além daquele tradicional em que eram inseridas simplesmente pelo seu gênero. Desse modo, o olhar sobre a 
feminilidade, a partir do viés literário, expandiu a compreensão dessa nova mulher (GARCIA, 2015). As prosadoras cabo-verdianas abordam os mais diversos temas em suas obras, de modo a incluir no cotidiano características e realidades distintas, além dos preconceitos sofridos em uma sociedade ainda androcêntrica (GOMES, 2008).

O presente trabalho analisa três perfis de mulheres expostos em seis contos da obra Semear em Pó (1994), de Fátima Bettencourt, são eles: "As mantas de mamã", "Mucula", "Boa Raça", "Secreto compasso", "Vavá" e "As mulheres que meu pai amou". Para a análise, levaremos em conta a voz e a pessoa dos narradores (GENETTE, 2017). Destacamos que das seis narrativas analisadas, quatro apresentam narradores homodiegéticos, uma é autodiegética e uma é heterodiegética. Essa primeira pessoa pode ser alguém que relata suas memórias e assume a pessoa de personagem principal e narrador de sua experiência (autodiegético) ou desempenha um papel de observador e testemunha (homodiegético), sendo fulcral para o traçado dos perfis das personagens femininas. Consideramos o narrador o elemento principal porque ele é o organizador da história, assim como é por ele que sabemos os fatos. Assim, neste trabalho, percebemos que, na narração homodiegética, o testemunho serve como uma espécie de prova do que as personagens passaram; na narração autodiegética como uma forma de confissão e na narração heterodiegética o meio de contar o que não foi possivel testemunhar ou declarar (GENETTE, 2017, p. 323-325).

Entendemos por perfil feminino as novas identificações que as mulheres encontram para si mesmas. Assim, percebemos nas narrativas da obra analisada uma nova caracterização dessas personagens como sujeitos independentes, com voz ativa e que decidem os rumos de suas vidas, visto que elas próprias transmutam os seus modos de ser e de viver em meio à sociedade, desmontando as visões patriarcais que as caracterizavam até então. A mulher que é mãe, guerreira, independente, nessas histórias, complementam umas às outras e tais características podem ser encontradas em mais de um conto, obviamente, com as suas particularidades. Desse modo, podem ser encaradas como "tendo identidades que se transformam, que não são fixas ou permanentes, que podem, até mesmo, ser contraditórias" (LOURO, 2004, p. 24). Portanto, esse movimento de autorrepresentação de suas condutas, constitui um novo olhar, pois nos deparamos com mulheres escrevendo sobre mulheres e, assim, passamos a ter uma legitimação dessa literatura e desse discurso, já que são elas levantando questões e identificações próprias e de outros seres femininos.

Dentre as autoras cabo-verdianas que colaboraram para a inserção do feminino na literatura está Hirondina de Fátima Bettencourt Santos Lima, mais conhecida somente por Fátima Bettencourt. Nasceu em 16 de fevereiro de 1938, na Itha de Santo Antão, mas cresceu em São Vicente, onde frequentou o Liceu. Diplomada em Magistério Primário, estagiou em Comunicação Educacional na Universidade Nova de Lisboa e na Escola Superior de Educação de Setúbal, em Portugal. Além da carreira docente, trabalhou no meio jornalístico, sendo locutora e produtora de programas radiofônicos em Cabo Verde, Guiné-Bissau e Angola. Atualmente é produtora e apresentadora de programas da Rádio Educativa de Cabo Verde.

Todas essas atividades caracterizam-na como uma mulher ativa e presente não só em diversas áreas, mas também na sociedade. Como escritora, publicou contos e crônicas. No primeiro gênero há Semear em Pó (1994), Mar, caminho adubado de esperança (2001) e Sonhos e desvarios (2019). No segundo, Um certo Olhar (2001) e Lugar de suor, pão e alegria (2008). O livro infanto-juvenil A cruz de Rufino foi publicado em 1996. Fátima Bettencourt participa ativamente na luta das mulheres por igualdade social e de gênero, fato perceptivel em suas obras (GOMES, 2008).

\section{A condição feminina}

Toda a história das sociedades foi marcada por desigualdade entre homens e mulheres, porque, infelizmente, a mulher era vista como inferior pelos homens. Dessa forma, o Feminismo pode ser definido como: 
A tomada de consciência das mulheres como coletivo humano, da opressão, dominação e exploração de que foram e são objeto por parte do coletivo dos homens no seio do patriarcado sob suas diferentes fases históricas, que as movem em busca da liberdade do seu sexo e de todas as transformações da sociedade que sejam necessárias para este fim (GARCIA, 2015, p. 13)

Essa tomada de consciência por parte das mulheres fez com que muitas das mentiras atribuidas à necessidade de subordinação ao homem fossem desmentidas. Por meio do feminismo, os olhares voltaram-se para o fim do machismo que está alicerçado em vários setores da sociedade: no trabalho, no ambiente familiar, entre amigos, na publicidade e nas artes. A mulher foi vista como coisa, um objeto descartável e, ainda hoje, muitos discursos propagam essa visão.

O Androcentrismo, que considera o homem como medida de todas as coisas, distorce a realidade, trazendo consequências para a vida cotidiana, tal como destaca Carla Cristina Garcia (2015, p. 16),

Enfocar um estudo, uma análise ou pesquisa a partir unicamente da perspectiva masculina, e utilizar os resultados como válidos para todo o resto do mundo, faz com que todo o conhecimento produzido não seja confiável, ou, no mínimo, tenha enormes lacunas e confusões. Um bom exemplo de androcentrismo são os meios de comunicação. A visão androcêntrica do mundo decide e seleciona quais fatos, acontecimentos ou personalidades são notícias, quais serão primeira página e a quem ou ao que dedicar tempo e espaço. Essa mesma visão também decide quem o explicará diante dos microfones, quem dará a chave dos acontecimentos. Como os meios de comunicação configuram a visão que a sociedade tem do mundo, perpetuam, em pleno século XXI a visão androcêntrica.

Dessa forma, há somente uma perspectiva para todas as coisas: a masculina, sendo a única verdade. Resulta-se disso que a mulher é somente espectadora, sem direito à voz e à representação. O patriarcado, cria da visão androcêntrica, é, segundo os estudos feministas dos anos 1970 ,

Forma de organização política, econômica, religiosa, social baseada na ideia de autoridade e liderança do homem, no qual se dá o predomínio dos homens sobre as mulheres; do marido sobre a esposa, do pai sobre a mãe, dos velhos sobre os jovens, e da linhagem paterna sobre a materna. O patriarcado surgiu da tomada de poder histórico por parte dos homens que se apropriaram da sexualidade e a reprodução das mulheres e seus produtos: os filhos, criando ao mesmo tempo uma ordem simbólica por meio dos mitos e da religião que o perpetuam como única estrutura possivel (GARCIA, 2015, p. 16-17).

A manutenção do poder nas relações homem versus mulher dá-se tanto no âmbito pessoal quanto no profissional. Por exemplo, no primeiro, em casos de relacionamentos abusivos, violência doméstica e estupro. No segundo, em disparidade salarial (mesmo ambos tendo a mesma formação) e assédio. Ainda no século XXI há figuras que perpetuam o discurso patriarcal, unindo o machismo, o racismo e a homofobia, através da violência física e psicológica, conforme destacado por Carla Cristina Garcia (2015).

As mulheres ficam, como considera Marcia Tiburi, em Feminismo em Comum Para Todas, Todes e Todos (2018), no lugar de "carne", pois não competem em igualdade de direitos com os homens. Dessa forma, as conquistas transformam-se em "vitórias paradoxais", que Carla Cristina Garcia exemplifica:

\begin{abstract}
Nas sociedades ocidentais contemporâneas, as mulheres conseguiram o direito à educação e ao trabalho remunerado, mas a maioria daquelas que trabalham fora de casa, tanto as assalariadas quanto as autônomas, continuam encarregadas do trabalho doméstico e do cuidado com os filhos. É a dupla jornada ou a dupla presença. Mesmo aquelas que conseguem delegar essa tarefa também o fazem sobre outras mulheres mais pobres ou mais velhas: as empregadas domésticas e as avós (GARCIA, 2015, p. 17-18).
\end{abstract}

Para melhor ilustrar isso, daremos dois exemplos no que diz respeito não só à publicação, mas também à visibilidade. Uma pesquisa feita sobre a autoria de obras entre os anos de 1950-1955 na França, apresentada por Marcelle Marini, demonstra que $75 \%$ eram escritas por homens e $25 \%$ por mulheres. $O$ retrato do autor que tem possibilidades de escrever e se dedicar somente a isso "é macho, de boas famílias e com educação superior, publica em Paris e dispõe de uma rede poderosa de amizades e de relações profissionais." (MARINI, 1995. p. 363). Dessa forma, as mulheres que não 
têm esses privilégios e ainda têm de lidar com as tarefas familiares possuem menos oportunidades e tempo disponivel para a criação literária.

No Brasil, um estudo semelhante foi feito por Regina Dalcastagné (2018) e chegou a resultados não muito diferentes, 60 anos depois. Logo, o homem branco heterossexual possui mais oportunidade de se dedicar ao trabalho intelectual do que uma mulher e muito mais do que uma mulher negra, tal como a autora aqui estudada.

Segundo Carla Cristina Garcia (2016, p. 106), "a palavra impressa é frequentemente patrimônio do grupo dominante e usada para reforçar a invisibilidade cultural, as vozes dos grupos dominados se encontram relativamente ausentes destas narrativas". Em Cabo Verde, a partir da década de 1990, a situação das escritoras sofreu modificações, pois um número maior viu suas obras publicadas. Essas mulheres passam a ter não somente voz, mas também uma visibilidade maior dentro e fora do arquipélago. Assim, puderam contar as suas histórias (a das mulheres das ilhas) das suas formas. Os grupos de escritoras, de ativistas contribuem para

uma genealogia feminina, que recupere protótipos literários e mitológicos, galeria de mulheres ilustres que busque a construção do imaginário, da simbologia, da memória e da presença feminina e que inclua portanto mulheres reais e fictícias, feministas ou não (GARCIA, 2016, p. 108).

Na obra de Fatima Bettencourt temos a figura feminina em primeiro plano, tal como veremos a seguir.

\section{Semear em pó: contos}

A escrita de Fátima Bettencourt, iniciada na década de 1990, apresenta traços da contemporaneidade: as conquistas das mulheres cabo-verdianas em relação a outras épocas, retratando lembranças de periodos ruins pelos quais passou - País e os problemas advindos daí. Para Simone Caputo Gomes (2008, p. 9),

Em Semear em pó: contos, também constrói as narrativas a partir da presença feminina, colocando-a sempre em relação com personagens chave do círculo familiar ou do mundo crioulo. O fio condutor centra-se na menina ou adolescente que narra, compondo um vitral de fragmentos de recordações, "quadros vivos" em que a figura da mãe domina o universo familiar e se expande para comunidade.

Vemos acima a importância da mulher para o desenvolvimento da sociedade cabo-verdiana. A partir do momento que obteve o seu espaço, aproveitou-se disso para a contribuição dos aspectos que necessitavam de atenção no cotidiano das pessoas. No seio familiar, deixa de ser somente a protetora dos filhos e passa a se dedicar também à comunidade.

$\mathrm{Na}$ obra, a figura feminina surge com papel mais ativo. Existe, igualmente, o cunho memorialista ao retratar os periodos dificeis de seca, fome e a ausência de quase tudo que é básico para a sobrevivência. Da mesma forma, a autora apresenta seus personagens a partir de um olhar ingênuo, uma forma de aprendizado, visto que a maioria dos narradores são jovens. A mulher surge como personagem principal em quase todos os contos aqui analisados. Essa nova mulher, de certa forma, busca a realização pessoal e o crescimento próprio. Entretanto, cabe ressaltar que, ao longo da toda a obra, conforme Monteiro e Dal Cortivo (2017, p. 9), há um

\begin{abstract}
equilibrio/equidade de gênero, isto é, apesar de suas vozes narrativas femininas serem a maioria esmagadora, sugerindo a prevalência do feminino, o protagonismo é o mais equânime, tendendo para o desejo/utopia social de igualdade, em que se registram como personagens mulheres empoderadas e homens reconciliados, ou ao menos um mundo menos falocêntrico do que na escrita de Orlanda Amarilis e Ivone Aida.
\end{abstract}

Assim, tem-se novas representações das masculinidades, quer dizer, o homem já não é aquele ser que enxerga a mulher somente como objeto e que se põe no lugar de superior. Esse homem está amadurecido e sua mentalidade está modificada, pois ele sabe dividir o espaço com a mulher, que é dona de si e procura fazer seu papel na sociedade. Isso tudo, graças às lutas enfrentadas a partir da década de 1990, como criações de medidas para garantir direitos mais igualitários entre os gêneros, salientados por 
Simone Caputo Gomes (2008). O nosso recorte aqui, contudo, é o de analisar as representações da figura feminina na obra.

Há duas histórias em "As mantas de mamã". A primeira é a tradição de Nhô Silvestre e sua familia de tecelões, de forma que "Dominando uma por uma as técnicas ancestrais, exemplificava cada uma das fases desde a limpeza da lã à separação, cardação, fiação, até os fios chegarem ao tear, agora sim manipulados apenas por ele" (BETTENCOURT,1994, p. 13-14). A segunda é a curiosidade da filha (narradora) em saber o porquê de sua mãe querer tantos cobertores de lã.

Quando a mãe dela chegou em Santo Antão, vinda de São Vicente, ninguém sabia o motivo dela ter parado ali. Com o tempo, ela passou a ajudar a todos, obtendo a admiração até de quem a via com maus olhos. Ela não só comprava as mantas para ajudar os pobres que necessitavam de algo para afastar o frio, mas também possibilitava a Nhô Silvestre o sustento contra a fome e a pobreza. Afinal, era somente aquilo que o ancião sabia fazer na vida. No final, a narradora questiona-se: foi um sonho ou uma invenção para distraí-la?

A figura da mãe no conto adquire ares de "santa" por ajudar aos que mais necessitavam. Percebe-se, por meio da descrição, que a personagem faz parte de uma classe social mais alta. Na visão de Fátima Bettencourt, na sociedade cabo-verdiana, a mulher pode desempenhar qualquer papel, incluindo ser a chefe de familia, com bens, e ser a benfeitora daqueles que a cercam. O título do conto revela a preocupação da narradora: a história de Nhô Silvestre serve para ilustrar o papel que sua mamã desempenha naquela comunidade. Outro fato importante a ser destacado é que há mãe, mas não há pai. Ao contrário de outros contos em que as mulheres são abandonadas, neste nada a respeito disso é mencionado, nem a fonte do dinheiro da mãe da narradora, o que corrobora para a independência da figura feminina.

Na narrativa, uma mulher passa a ser a heroína, na visão dos mais velhos. Ao mesmo tempo, os anciões são valorizados por essa mãe pelo que são: pessoas sábias que viveram muito, sempre desempenhando uma só função, em virtude da tradição familiar. A narradora não se preocupa em dar as características físicas da mãe, mas se dedica a exibir as boas ações a partir das quais ela tira da miséria absoluta algumas pessoas, tal como vemos em: "Oh menininha de Deus, tua mãe é uma santa [...] tomou conta da escola, tomou conta de todos nós desta ribeira e já não sabemos passar sem ela" (BETTENCOURT, 1994, p. 16).

No ensaio "Flashes de estética comparada: lendo imagens cabo-verdianas", Simone Caputo Gomes (2010) utiliza pinturas de artistas de Cabo Verde para estabelecer relações com a literatura do país. Dessa forma, os pintores Kiki Lima e Sandro Brito são interlocutores do texto de Fátima Bettencourt. Para Gomes (2010, p. 61),

as mulheres, na obra de Kiki Lima, são repre-
sentadas numa ótica feminina de focalização
e valorização, como se o pintor se tornasse
cúmplice de suas vozes, que contam uma tra-
jetória de labuta diária e de construção do país
por meio de um contra discurso que emana
do campo cotidiano do miúdo e do detalhe
[.... Sinais de uma natureza outra, diversa do
épico masculino dos grandes feitos, constroem
a historicidade feminina em Cabo Verde.

Portanto, a mudança de foco proporcionou não só uma transformação na visibilidade como também garantiu às mulheres uma nova voz que destaca os diferentes papéis que elas adquiriram na sociedade cabo-verdiana. Dessa forma, a narradora homodiegética de "As mantas de mamã", provavelmente já adulta, mas com o olhar e a inocência infantil diz "Guardo até hoje na memória [...]" (BETTENCOURT, 1994, p. 14). Essas lembranças são importantes para caracterizar as relações no conto. Nhô Silvestre é o homem que coordena todo o trabalho de tecer as mantas, mas ele (e todas as mulheres envolvidas nas etapas de fabricação) é dependente da mãe da narradora. A curiosidade da criança, que sempre fazia a mesma pergunta de diferentes formas, é saciada com uma revelação: a mãe não compra por necessidade própria, mas para ajudar várias familias que dependiam daquele trabalho. O ancião, ao responder, tem de passar por cima do seu orgulho masculino e reconhecer a importância (e a bondade) daquela mulher de fora da ilha que, naquele momento, sustenta a toda uma comunidade. 
A criança que vivenciou os fatos não é a narradora que conta a história, mas lembra-se de detalhes que sua mãe diz não ser possivel em "Mucula". Contudo, como se fosse um filme, as memórias daquele acontecimento marcaram-na profundamente, apesar de ter apenas dois anos e meio. Mucula, cujo nome é Marcolino, irmão de criação da narradora, é encontrado chorando por ela. Ao questionar o motivo, ele responde que sua mãe havia morrido. Ajovem não compreende essa segunda morte da mãe, pois ele morava com a familia dela. Mucula, então, explica-lhe que a mãe dele era louca e cortou o umbigo (na verdade, o cordão umbilical, termo que ele mesmo não conhece) dele com uma pedra.

A narradora fica impressionada, o que demonstra a inocência da menina: "Levantei meu vestidinho e fiquei olhando para o meu próprio umbigo matutando sobre o que havia ali para cortar à pedrada" (BETTENCOURT, 1994, p. 18). Além da ingenuidade da menina, é mostrado um hábito frequente na sociedade cabo-verdiana, segundo Simone Caputo Gomes (2015), que é a familia estendida, ou seja, uma pessoa é adotada por uma familia com condições de criar. Esse fato denota a generosidade e a compreensão da mãe da narradora em adotar e criar um filho que não é seu.

A narrativa homodiegética de "Mucula" relata o inusitado da situação: "Mamãe diz que é impossivel eu me recordar dessas coisas mas na verdade vejo-as desfilar como num écran, em quadros vivos, porém nebulosos [...]" (BETTENCOURT, 1994, p. 17) A mulher que conta é a adulta a partir de suas memórias, porém, apesar da vívida lembrança dos fatos, inclusive de diálogos, há a ingenuidade da criança que não compreende, de fato, o que está a ouvir.

"Boa raça" narra a história de Prima Antónia, uma mulher sofrida, trabalhadora e corajosa. Depois de tudo o que passou na vida, aprendeu a não ter papas na língua: se julgava algo errado, falava sem medo. Sofreu, primeiro, em casa com os serviços domésticos, depois ao ver toda a família morrer de fome e, por último, nas roças de São Tomé. O trabalho tirou-lhe a saúde também, acabou adoecendo, teve tuberculose e, assim, recebeu os cuidados de uma prima do interior que lhe trouxe comida, roupas limpas e remédios. Ficou internada no hospital, recebendo a admiração de todos, ao ponto de, depois de curada, ser convidada a trabalhar de servente. Contudo, no dia em que ameaçou esbofetear um médico, acabou sendo demitida.

Depois disso, passou a viver com uma parente mais velha, e eram amparadas financeiramente por "um sobrinho, a bem dizer primo em terceiro ou quarto grau que subira na vida" (BETTENCOURT, 1994, p. 31). Quando a outra senhora morreu, passou a viver sozinha, indo sempre ao trabalho do sobrinho que, conhecendo-a, sabia que ela não aceitaria a humilhação de somente pegar o dinheiro, por isso a recebia em seu gabinete, conversavam e dava-lhe o dinheiro. Quando morreu, Prima Antónia deixou o legado de mulher corajosa que não se conformava com pouco.

O conto tem dois períodos históricos distintos: um antes da Independência e outro depois. No primeiro periodo, apresenta a forma como as mulheres eram tratadas nas fazendas pelos colonos. Se fossem de "boa raça", isto é, brancas ou mestiças trabalhariam na casa e as negras, na roça. Prima Antónia, que fora julgada de boa raça, não aceitou o rótulo. Ao retrucar, levou uma bofetada e foi enviada para trabalhar na roça. A situação de Prima Antónia denuncia o que os contratados sofriam: trabalhavam de sol a sol, passavam fome, mas, ainda assim, viam na emigração uma esperança de vida melhor. Monteiro (2015, p. 162) destaca que

Fátima Bettencourt, na caracterização da personagem protagonista, constrói uma figura feminina que afirma a insubmissão e a rebeldia das mulheres frente a um mundo de dominação simbólica masculina (representado pelo capataz colono, que usa da violência verbal e de gênero).

Dessa forma, Prima Antónia "deixou um legado de coragem e inconformismo, um patrimônio de dignidade e nobreza que é dever de cada um conservar intacto e passar às próximas gerações" (BETTENCOURT, 1994, p. 32). Esse é um modelo a ser seguido pelas mulheres no pós-independência em Cabo Verde. 
"Boa raça" é a única história das analisadas que não tem narração em primeira pessoa. Elencamos uma hipótese para isso, visto que a narradora não possui educação formal, logo, seria inverossimil ela fazer sua própria narração. Da mesma forma, como não há personagem que tenha acompanhado toda sua história, também uma testemunha seria improvável. Portanto, o narrador heterodiegético é o mais apto a contar a história de Prima Antónia.

Em "Secreto Compasso" é uma das filhas que narra a história de duas mães: a sua e a de Augusta, ex-empregada da família. A mãe é ocupada e exigente, não tendo paciência para empregadas domésticas, pois sempre se desagradava de algo nelas. Contudo, deixou-se render por uma: Augusta que fora tanto bem recomendada por uma comadre quanto bem acolhida pelas crianças da casa.

Apesar de estar sempre cantando, nunca deixou de realizar as tarefas da casa com zelo, mas, certo dia, Augusta não apareceu para trabalhar e mandou um recado de que não estava bem por conta da gravidez. Depois de meses fora da casa, ela retornou com uma criança em seus braços. Agora, magra e sofrida, Augusta não irradiava mais aquela alegria de antes. Outra vez, as crianças insistiram para que a mãe a acolhesse novamente em casa e ela aceitou.

Após algum tempo, Augusta parecia ter retomado o juízo e o gosto pela vida. Contudo, a mãe temeu ao ouvir a jovem voltar a cantarolar cantigas que considerava obscenas. E estava certa. Augusta sumiu novamente. Ao reencontrá-la, já no estágio final da Tuberculose, descobriram o que se passou: um homem a levou para Santo Antão, onde passou a trabalhar na estrada e contraiu a doença. Igualmente, descobriram que ela teve outro filho, que morreu nos tempos em que estava trabalhando na estrada. O primeiro filho foi criado pela familia e vive atualmente na Suécia, dedicando-se à música nas horas livres. Esse gosto é visto como herança de sua mãe.

O conto nos apresenta dois tipos diferentes de mãe: a primeira, uma madura chefe de familia, forte e exigente. A segunda, uma moça com a sexualidade aflorando, sem medir consequências. Manuel Pedro Monteiro (2014, p. 164) destaca que

\begin{abstract}
A matriarca e Augusta se opõe diametralmente no conto: aquela representa a retidão e a honra, aos moldes patriarcais; Augusta, considerando o mesmo modelo, situa-se no polo oposto, pois assume um comportamento condenado pela masculinidade hegemônica, numa dicotomia pecadora $X$ santa.
\end{abstract}

Há, ainda, no conto, traços de problemas reais da sociedade cabo-verdiana: a desinformação e a marginalização das mulheres das classes mais baixas geravam a falta de participação delas nas lutas pela emancipação feminina. Da mesma forma, provocavam problemas de maternidade precoce, a falta de oportunidades, fazendo com que muitas tivessem de trabalhar em qualquer coisa que surgisse.

A narradora homodiegética do conto deixa claro a sua falta de consciência do que presencia em virtude da pouca idade, pois ela era criança no tempo dos acontecimentos da história. Diz ela sobre Augusta: "Irradiava dela uma chama que na época eu não soube compreender mas agora não me surpreende que se mantivesse cessa e nítida nas minhas lembranças de muitos anos atrás" (BETTENCOURT, 1994, p. 34). Agora, madura, percebe as diferenças entre as duas mães: a sua e a jovem empregada da casa. A sua mãe, apesar de rígida e apreensiva, era também solidária, pois acolheu Augusta duas vezes e criou o filho como um dos seus.

A narradora autodiegética de "Vavá" relata a história de uma paixão impossivel de sua juventude. A partir de um encontro com Vavá, anos após retornar a Cabo Verde, ela relembra como tudo começou: quando tinha 10 anos. Nessa época, Vavá beirava os 17, sendo quase um homem. Como ele era amigo do irmão dela, estava sempre na casa da familia. Apesar de o título do conto ser "Vavá" e, de certa forma, ele ser o personagem principal, a história realmente contada é a da narradora e a sua ligação com ele. De certa forma, a narrativa é uma espécie de amostra da culpa dela: "Qualquer coisa me inibe e me confrange quando encontro o velho amigo da infância, bem mais velho, é certo, mas a quem sem querer, marquei tão duramente" (BETTENCOURT, 1994, p. 45). 
Vavá nunca estudou além da $4 .^{\text {a }}$ classe, mas por ser desportista e bonitão, era desejado pelas raparigas. Dentre suas qualidades, a narradora destaca o corpo atlético, as pernas de jogador de futebol e uma generosidade imensa, "que parecia desafiar o mundo e os preconceitos" (BETTENCOURT, 1994. p. 45).

A menina cresce e toma consciência de que o futuro está longe da ilha. Ela sonha alto e percebe os dilemas a serem enfrentados:

Diferença de idades, diferença social, diferença de educação, todas as diferenças que os padrões e preconceitos da época nos ensinavam a colocar como barreiras entre nós e os outros. Eram diferenças a mais que eu não sabia gerir. Imaginava a minha vida de outro jeito. Queria estudar, ser alguém. Não sentia a minima vocação para vir a ser mais uma mãe de familia sacrificada, rodeada de criancinhas mal alimentadas e mal vestidas, caticatindo pela sobrevivência (BETTENCOURT, 1994, p. 46).

A vida e a sociedade seriam cruéis com ela se permanecesse em São Vicente. O primeiro namorado veio aos 17 anos e, aos 18, foi estudar em Lisboa. Aos 22, retorna à ilha. Vavá igualmente viu na emigração uma possibilidade de crescimento. Assim como a jovem, ele se transformaria em outro homem fora de São Vicente. Contudo, a vida não foi tão generosa com ele.

Ela seguiu sua vida: casou e teve três filhos. Anos depois, ao andar pela rua, avistou um homem e percebeu um olhar conhecido: era Vavá. Completamente diferente, o jovem bonito, deu lugar a um homem judiado pela vida. Conversam bastante nesse primeiro encontro, apesar de um certo desconforto de ambas as partes. Outros encontros, ainda que irregulares e casuais, fazem com que a velha cumplicidade retorne entre eles.

O conto evidencia a diferença de classes que existe em Cabo Verde. Percebe-se que, apesar de a personagem-narradora ser amiga de Vavá, ela reconhece a distância que existe entre eles por não pertencerem à mesma classe social, nem terem recebido a mesma educação e de que modo isso influenciou nas decisões dela sobre o rapaz. Ela também quis fugir do status quo ao querer uma vida diferente. Preferiu estudar e escapar da visão que a sociedade tinha sobre as mulheres: mães, esposas e donas de casa. Por meio da reflexão (estudo) e da ação (partir de Cabo Verde), ela transforma seu destino.

A mulher, aqui, participa de uma evolução, não mais se sujeitando ao modelo em que era vista como inferior ao homem. Agora são elas que alçam voos e transformam suas vidas, visto que, a partir da década de 1990, a literatura retrata uma nova visão sobre a mulher, como um ser que luta por algo, que toma e requer um lugar na sociedade. Pedro Manuel Monteiro destaca que, na mesma época,

\begin{abstract}
as mulheres cabo-verdianas já contavam com um avanço significativo de ações afirmativas, como a fundação do ICIEG - Instituto Caboverdiano para Igualdade e Equidade de Gênero e com planos de governo que tinham por meta a emancipação feminina (Plano de Ação Nacional para as Mulheres, 1996-2000; Plano Nacional de Desenvolvimento, 1997-2000; Plano de Luta contra a Pobreza) (MONTEIRO, 2015, p. 374).
\end{abstract}

No prefácio do livro Semear em pó, Moacyr Rodrigues aponta a forma como a autora procura, através das recordações da infância, fazer com que o leitor percorra o universo das ilhas de Cabo Verde. De certa forma, as narrativas são "[...] um feixe de recordações e informações de infância, numa linguagem fluente onde as palavras se combinam para nos fazer viajar no tempo para o universo ilheno [...]" (RODRIGUES, 1994, p. 7). A memória é, assim, uma caracteristica determinante na escrita de Fátima, pois as lembranças estão interligadas ao tempo em que se passam as histórias e, consequentemente, voltam-se para a forma como a sociedade está representada na ficção. Para Christina Ramalho (2009, p. 49), há a

\begin{abstract}
revelação de uma cultura, em que as mulheres figuram como sustentáculo para a perpetuação da identidade pátria, as narrativas de Fátima deixam em aberto possibilidades de reflexões crítico-feministas sobre as condições existenciais dessas mulheres.
\end{abstract}

Nos contos aqui analisados talvez não haja características tão reivindicatórias de pautas feministas, mas há neles a descrição de uma mulher dona de si, aquela que quer um futuro melhor e que não se imagina somente como dona de casa 
e mãe. As mulheres das narrativas derrubam esse estereótipo e propõem uma nova vida, um novo rumo com novas ideias para o futuro, tal como quando a narradora de "Vavá" percebe que seu futuro era longe de sua terra natal e diferente do de muitas mulheres do arquipélago.

Se na maioria dos contos do livro as narradoras são mulheres, temos em "As mulheres que meu pai amou" o único narrador masculino da coletânea. Assim, a narrativa homodiegética funciona como uma espécie de organização dos diferentes relatos que há sobre o seu pai. Ao organizar essas histórias, ele tenta recuperar a história do seu progenitor, mas o que, de fato, ocorre é a narração da história das mulheres de Cabo Verde. O conto inicia com o personagem fazendo planos de viagem de férias em Cabo Verde. Ele relata que tem irmãos em todas as ilhas, exceto Santa Luzia, pelo fato de essa não fazer parte da rota de navegação costeira. 0 pai dele encontrou um amor diferente em cada ilha e a todas amou igualmente.

Nita, a mãe do personagem, sempre viveu em São Vicente. Apesar de ser criada em uma familia conservadora e religiosa, logo voltou-se contra esses principios e foi trabalhar por conta própria, tornando-se modista de vestidos e chapéus em seu próprio ateliê com seis ajudantes. Em uma embarcação argentina, com o objetivo de aprender a dançar tango, acabou conhecendo o pai de seu filho. Ela sentiu-se atraída por aquele homem requintado; ele fascinou-se por aquela jovem independente, segura e batalhadora, tal como Ramalho (2009, p. 51) destaca: "é na perspectiva da subjetividade da personagem Nita que se evidenciam os primeiros traços da peculiaridade que define a familia que será formada".

Em sua ilha natal, Santo Antão, o pai do narrador sempre se hospedava na casa de alguns parentes. Lá ele conheceu Ana Maria, jovem de pele branca e olhos azuis, muito tímida e extremamente prendada. Além disso, seu talento, de acordo com o narrador, era sua voz, que só cantava na igreja. Com a convivência, surgiu a paixão e o noivado. Contudo, com a morte repentina do noivo, a jovem teve de encarar um outro problema: estava grávida.
Na ilha de Boa Vista, em uma de suas andanças, o pai conheceu Chencha. Em Sal Rei, ela ocupava o lugar de homem da casa desde que seu pai morrera, por esse motivo não queria perder sua liberdade e dizia não necessitar de homem. A jovem conheceu o pai do narrador enquanto apanhava lagosta. Logo que o viu, sentiu uma sensação que nunca antes sentira. Daquela união tão inusitada, Chencha teve uma menina, "tão parecida com o pai" (BETTENCOURT, 1994, p. 61). Chencha caracteriza-se por se afastar do modelo de feminilidade imposto pela época. Ela tem as mesmas características comumente relacionadas à masculinidade: força física e coragem. Da mesma forma, preza sua independência econômica e não se rende às amarras tradicionais, que pressionam as mulheres a casar e a constituir familia.

Certa vez, o pai chegou à Brava, bem no meio da festa de São João. Lá conheceu Inês, natural de São Vicente, mas que ali trabalhava como professora. Mulher de personalidade forte, que não se importava com o que pensariam dela por ser solteira e andar com um homem que visitava a ilha às vezes. Devido ao fato de ser

Emigrada, afastada da familia, realizada profis-
sionalmente e esclarecida no que diz respeito à
critica de limites impostos pelo viriarcado, Inês
evidencia, como Chencha, uma faceta que esca-
pa ao modelo de submissão, pureza e fragilidade
apregoado pela cultura hegemônica para o com-
portamento feminino (MONTEIRO, 2014, p.184).

Com o tempo, aquela amizade tornou-se amor e um fruto dele é descoberto quase ao mesmo tempo em que a notícia da morte de seu amado é recebida. Mesmo sendo uma mulher que não se importava com as imposições da sociedade, ela acabou sofrendo com as punições que eram socialmente impostas para mulheres. Afinal, "Restava o filho no seu ventre porque até mesmo o emprego perdeu. A lei era intransigente. Funcionária do estado não podia ser mãe solteira" (BETTENCOURT, 1994, p. 62).

Essas são as histórias do pai, que o filho conheceu, a partir das próprias mulheres e de seus irmãos. Conforme Simone Caputo Gomes (2015, p. 142), 
Fátima Bettencourt centra o seu olhar, neste conto, sobre a familia estendida e o que se forma em seu entorno, aproxima-se das mulheres que comandam as atividades internas das casas, o funcionamento das familias, das mulheres que conduzem empresas ou das que são funcionárias do estado, enquanto o marido está fora correndo mundo. Evidenciam-se, assim, pela voz do narrador, focos de resistência ou de micro resistências, representados por personagens esclarecidas ou insubmissas. O conto torna-se expressão de um processo criativo consciente e de denúncia, aponta para uma diegese em passos gradativos rumo a um quadro de equidade social, pois, apesar das tragédias semeadas, há a sobrevivência e a superação por parte dessas mulheres ditas "amadas".

O caso de todas as mulheres que o pai amou pode ser visto como aventuras poligâmicas, mas que é justificado pelo narrador masculino como um comportamento vindo do amor desmedido que deixa consequências para as mulheres. Entretanto, apesar desse amor quase romântico, as mulheres são apresentadas como firmes, sendo elas responsáveis pelos trabalhos internos de casa, conduzindo empresas ou sendo funcionárias do Estado.

\section{Considerações finais: mãe, guerreira, independente}

Na década de 1990, Fátima Bettencourt, Dina Salústio, e outras escritoras e artistas já haviam enfrentado muitas barreiras pelas quais as mulheres precisam passar para constituir algum direito. Elas contribuiram para a transformação do papel da mulher na sociedade e a sua representação na literatura. A partir disso, percebemos distintos e complementares perfis de mulheres na obra de Fátima Bettencourt.

O primeiro que se destaca é o de mãe, aquela mulher perseverante que luta pela sobrevivência da família. É interessante notar que em nenhum dos contos a figura da mulher é caracterizada como submissa ao homem. Pelo contrário, é vista como batalhadora que, tendo marido ou não, é independente o suficiente para fazer suas próprias escolhas. Toda mãe, nos contos de Fátima Bettencourt, é guerreira e independente, apesar de já ter sofrido, não só por amor, mas também com as dificuldades da vida.
A mulher sempre é dona de si. Assim, nota-se que a escritora envolve a realidade que ela almeja em seus escritos. Exemplos disso são legíveis no conto "Boa Raça", no qual Prima Antónia era uma mulher de casa que cuidava dos filhos e marido, cozinhava, limpava e passava. Quando a fome levou toda a sua família, ela não se intimidou e buscou uma vida melhor. Ela nunca enfraqueceu ou se submeteu a humilhações. Os contos "As mantas de mamã" e "Secreto compasso" também exemplificam essa figura de mãe como sábia, bondosa, mas independente de homens.

No conto "Vavá", ocorre a desconstrução da visão patriarcal da mulher como um ser frágil que deve ser protegido, sem direitos. A narradora mostra que tem poder de escolha sobre a sua vida, optando por estudar e sair do País. Casa-se, separa e não vê problemas nas diferenças sociais, educacionais e de idade que a separam de Vavá.

A partir do conto "As mulheres que meu pai amou", é possivel fazer uma abordagem de todos esses perfis e, com isso, evidenciar com mais profundidade os traços que demonstram a independência das mulheres em relação ao homem. O conto desconstrói a imagem de que a mulher deve obedecer a tudo que o patriarcado as impõe, pois apresenta as diferentes formas de resistência individual de cada uma das mulheres amadas pelo pai do narrador. Ainda é possivel perceber que, apesar de o filho ser um grande admirador de seu pai, ele não é um continuador de suas ações.

Ao colocar a voz em um narrador masculino, a autora apresenta uma reflexão sobre esses diferentes modos de ser das mulheres. Temos, nessa narrativa a maior representatividade feminina da obra. Não é por acaso que esse é o último e mais longo conto da obra.

Há o desmonte de uma visão patriarcal de muIheres perfeitas, belas e puras que são dominadas por homens, visto que todas assumem a responsabilidade sobre o seu sustento e dos filhos, sem necessitar da ajuda do homem que tanto amam. O pai do narrador, um Don Juan cabo-verdiano, nunca proveu nada, quer financeiramente, quer afetivamente a todos os seus filhos. O que sobra é a memória, recuperada por esse filho que busca um pai que, de fato, nunca existiu. 
Os perfis são muito diferentes: mãe, guerreira, independente e as intersecções entre elas, as tornam batalhadoras, pois o amor que depositaram no marinheiro não as fez submissas a ele. Pelo contrário, ele não esteve presente na vida delas (e de seus filhos). Todas perceberam que seu dever era resistir contra as imposições de quem quer que fosse. Elas lutaram para ter o direito de se sentirem seguras, aceitas e respeitadas dentro da sociedade, porque sabiam que não tinham nascido com os mesmos privilégios que os homens.

O narrador tenta demonstrar que amar e ser amada é algo necessário, porém o amor não pode ser sinônimo de repressão ou de objetificação. Vemos mulheres como seres providos de inteligência, razão e força, que não deixam sua liberdade ser apagada de sua vida por uma relação amorosa.

Na obra de Fátima Bettencourt, foi possivel identificar fatos da História recente de Cabo Verde que contribuíram para uma escrita comprometida com o papel da mulher na sociedade do país. As personagens femininas de Semear em pó revelam não ser aquilo que o patriarcado quer; muito pelo contrário, todas já estão em um ritmo avançado em relação a isso. Ainda que algumas pertençam aos extratos mais baixos da sociedade, elas têm a sua rebeldia e liberdade, que as fazem escapar de um estereótipo. Temos, portanto, mulheres inseridas nas diferentes esferas sociais, desempenhando algumas o papel de heroínas, outras o sinônimo de bondade e coragem. A junção desses elementos forma um tipo de resistência que, pouco a pouco, leva a uma emancipação social, ao ponto de nenhuma das personagens dos contos aqui analisados depender diretamente de homens.

\section{Referências}

BETTENCOURT, Fátima. Semear em Pó. Praia: Ministério da Cultura e Comunicação e Instituto Cabo-verdiano do Livro e do Disco, 1994.

DALCASTAGNÉ, Regina. Quem é e sobre o que escreve o autor brasileiro. Revista Cult, [s. l.], 2018. Disponivel em: https://revistacult.uol.com.br/home/quem-e-e-sobre-o-que-escreve-o-autor-brasileiro/. Acesso em: 09 jul. 2019.

GARCIA, Carla Cristina. Breve História do Feminismo. São Paulo: Claridade, 2015.
GENETTE, Gérard. Figuras III. São Paulo: Estação Liberdade, 2017.

GOMES, Simone Caputo. Cabo Verde: literatura em chão de cultura. São Paulo: Ateliê, 2008.

GOMES, Simone Caputo. Flashes da estética comparada: lendo imagens cabo-verdianas. Revista Abril. Niterói, v. 3, n. 5, p. 45-64, nov. 2010

https://periodicos.uff.br/revistaabril/article/ view/29763/17304 Acesso em: 10 jul. 2019.

GOMES, Simone Caputo; MANTOVANI, Antonio Aparecido; PEREIRA, Érica Antunes (org.). Literatura Cabo-verdiana: leituras universitárias. Cáceres: Ed. UNEMAT, 2015

LOURO, Guacira Lopes. Gênero, sexualidade e educação: uma perspectiva pós estruturalista. 6. ed. Petrópolis: Editora Vozes, 2003.

MARINI, Marcelle. O lugar das mulheres na produção cultural. In: DUBY, Georges; PERROT, Michelle (ed.). História das mulheres no Ocidente: o século XX. Porto: Afrontamento, 1995. p. 351-379.

MONTEIRO, Pedro Manoel. Os caminhos da ficção cabo-verdiana produzida por mulheres: Orlanda Amarilis, Ivone Ainda e Fatima Bettencourt. 2014. 256 p. Tese (Doutorado) - Faculdade de Letras, USP, São Paulo, 2014. Disponivel em: https://teses.usp.br/teses/ disponiveis/8/8156/tde-13052014-122142/pt-br.php Acesso em: 2 maio 2019.

MONTEIRO, Pedro Manoel. Os caminhos da ficção cabo-verdiana: Resistência e representação. Errâncias do imaginário. Porto: Universidade do Porto, Faculdade de Letras, 2015. p. 356-377. Disponivel em:

https://ler.Letras.up.pt/uploads/ficheiros/13436.pdf Acesso em: 11 jun. 2019

MONTEIRO, Pedro Manoel; DAL CORTIVO, Raquel Aparecida. O Bildungsroman feminino nos contos Cabo Verdianos. Estação Literária, Londrina, v. 18, p. 57-70, jul./dez. 2016. Disponivel em: http://www.uel. $\mathrm{br} / \mathrm{revistas} / \mathrm{uel} / \mathrm{index} . \mathrm{php} / \mathrm{estacaoliteraria/article/}$ view/29131/20884

Acesso em: 11 jul.2019.

RAMALHO, Christina. "As mulheres que meu pai amou", Mulher e cultura cabo-verdianas no conto de Fátima Bettencourt. Revista Ártemis, João Pessoa, v. 10, p. 45-58, 2009. Disponivel em: https://periodicos.ufpb.br/ojs2/ index.php/artemis/article/view/11825/6879

Acesso em: 12 jul. 2019

TIBURI, Marcia. Feminismo em comum, para todas, todes e todos. Rio de Janeiro: Rosa dos tempos, 2018

\section{Demétrio Alves Paz}

Doutor em Teoria da Literatura pela Pontifícia Universidade Católica (PUCRS), em Porto Alegre, RS, Brasil; professor Associado de Teoria Literária e Literaturas de Lingua Portuguesa da Universidade Federal da Fronteira Sul (UFFS), em Cerro Largo, RS, Brasil. 
12/12 Navegações, Porto Alegre, v. 13, n. 2. p. 1-12, jul.-dez. 2020 | e-35580

Letícia Gabriele Drey

Graduanda em Letras na Universidade Federal da

Fronteira Sul (UFFS), em Cerro Largo, RS, Brasil; foi bolsista de Iniciação Científica do CNPq e da FAPERGS.

\section{Endereço para correspondência}

Demétrio Alves Paz

Av Assis Brasil, 4908, apto 1407, bloco 3

São Sebastião, 91110000

Porto Alegre, RS, Brasil

Letícia Gabriele Drey

Rua Neco Januário, 582, apto 4

Centro, 97900000

Cerro Largo, RS, Brasil 